\title{
Incidence of diabetes mellitus at postpartum six to twelve months following the diagnosis of gestational diabetes mellitus
}

\author{
Gestasyonel diyabetes mellitus tanisı sonrasinda postpartum 6-12. aylarda \\ diyabetes mellitus saptanma oranlar
}

\author{
Özlem Seçilmiş Kerimoğlu, Serdar Yalvaç, Deniz Karçaaltınçaba, Ömer Kandemir
}

Etlik Zübeyde Hanım Women's Health Teaching Hospital, Ankara, Turkey

\section{Abstract}

Objective: The aim of this study was to research the rates of diabetes mellitus (DM) and the risk factors that may play a role in the prediction of this condition by evaluating patients with the diagnosis of gestational diabetes mellitus (GDM) at the $6^{\text {th }}-12^{\text {th }}$ postpartum months.

Material and Method: Among 109 cases who had been invited to the hospital for oral glucose tolerance test (OGTT) at the $6^{\text {th }}-12^{\text {th }}$ postpartum months, 84 cases (77\%) were enrolled in the study. To the 78 patients that were found to be appropriate according to the study criteria, 75 gr OGTT was administered. Patients who had new pregnancies during the period of postpartum screening, and those with previously diagnosed DM were excluded from the study.

Results: While the results of 23 cases (29.5\%) included in the study were normal, 27 cases (34.6\%) were diagnosed with DM and 28 cases (35.9\%) were diagnosed as having an impaired glucose tolerance and /or impaired fasting glucose (IGT/IFG). Among patients diagnosed with DM, the history of DM in the first degree relatives $(n=21,77.8 \%$, $\mathrm{p}=0.018$ ), body mass index before pregnancy (mean $=30.1 \pm 4.4$, $\mathrm{p}=0.009)$ and insulin requirement for the treatment of GDM $(n=25$, $92.6 \%, \mathrm{p}<0.05)$ were determined at higher rates. In the logistic regression analysis, multiparity $(\mathrm{OR}=2)$ and insulin requirement during pregnancy (OR: 7.27) were found to be the predictive factors in the development of postpartum DM.

Discussion: In this study, the determination of high rates of DM development in the postpartum period after GDM demonstrates the necessity of augmentation in efforts to increase the screening rates after delivery and to increase the patients' acknowledgement of this topic. (J Turkish-German Gynecol Assoc 2010; 11: 89-94)

Key words: Gestational diabetes mellitus, postpartum, OGTT

Received: 20 February, 2010

Accepted: 11 April, 2010

\section{Introduction}

Gestational diabetes mellitus (GDM) is defined as the carbohydrate intolerance that first develops or is recognized during pregnancy (1). It develops due to impairment in the mechanisms physiologically compensating the increased insulin resistance and decreased insulin sensitivity during pregnancy, and the prevalence of GDM has been reported to

\section{Özet}

Amaç: Bu çalışmada gestasyonel diyabetes mellitus (GDM) tanısı alan hastaların postpartum 6-12.aylar arasında değerlendirilmesi sonucunda diyabetes mellitus (DM) saptanma oranları ve bu durumun öngörülmesine katkısı olabilecek risk faktörlerini araştırmak amaçlanmıştır.

Gereç ve Yöntemler: Postpartum 6-12. aylar arasında oral glikoz tolerans testi (OGTT) için hastaneye davet edilen 109 hastadan 84 (\%77) olgu çalışmaya başvurdu, çalışma kriterlerine uygun 78 hastaya 75 gr OGTT uygulandı. Postpartum tarama zamanında tekrar gebelik tespit edilen veya daha önce DM tanısı alan hastalar çalışma dışı bırakıldı.

Bulgular: Çalışma kapsamındaki hastalardan 23 (\%29.5) olgunun sonuçları normalken; 27 olguya (\%34.6) DM, 28 (\%35.9) olguya bozulmuş glikoz toleransı ve/veya bozulmuş açlık glikozu tanısı konuldu. DM tanısı alan hasta grubunda 1.derece akrabalarda DM öyküsü $(n=21, \% 77.8, p=0.018)$, gebelik öncesi vücut kitle indeksi (ortalama $=30.1 \pm 4.4, \mathrm{p}=0.009$ ) ve GDM tedavisi için insülin gereksinimi $(\mathrm{n}=25, \% 92.6, \mathrm{p}<0.05)$ daha fazla oranda tespit edildi. Yapılan lojistik regresyon analizi sonucunda multiparite $(O R=2)$ ve gebelikte insülin tedavisi gereksiniminin (OR: 7.27) postpartum DM gelişimi için öngörü faktörleri olarak değerlendirilebileceği tespit edildi.

Sonuçlar: Bu çalışmada GDM sonrası postpartum dönemde yüksek oranlarda DM gelişiminin tespit edilmesi, doğum sonrası tarama oranlarının artırılması ve hastaların bu konuda bilgilendirilmesi için daha çok çaba sarf edilmesinin gerekli olduğunu göstermektedir.

(J Turkish-German Gynecol Assoc 2010; 11: 89-94)

Anahtar kelimeler: Gestasyonel diyabetes mellitus, postpartum, OGTT Geliş Tarihi: 20 Şubat 2010

Kabul Tarihi: 11 Nisan 2010

vary between 1-14\% in many studies, depending on the population characteristics and diagnostic criteria (2). In Turkey, the prevalence of GDM has been reported as $4.48 \%$ in a study using the diagnostic criteria of Carpenter and Coustan $(3,4)$. In a great majority of patients with GDM, glucose tolerance returns to normal in the postpartum period. However, if pregnancy, which is a diabetogenic period itself, becomes complicated with GDM, the mother will be in the high risk group 
for the development of type 2 diabetes mellitus (DM) in the long term. In the postpartum period, the rate of type 2 DM development among GDM patients varies, depending on the ethnicity and follow-up period, and it is interesting that a prolongation in the follow-up period increases this rate. DM is a chronic disease that negatively affects the quality of life and continues progressively to destruction. For this reason, important targets in the postpartum follow-up of patients with GDM should include education of patients about their risks and what they could do to prevent or delay the development of DM (5).

In this study, it was aimed to investigate the rate of DM and the risk factors that may have a role in the prediction of this condition at the $6^{\text {th }}-12^{\text {th }}$ postpartum months, following the diagnosis of GDM.

\section{Material and Method}

The records of 335 patients who had been diagnosed with GDM and hospitalized for treatment between the dates of $1^{\text {st }}$ of January 2005 and $31^{\text {st }}$ of December 2007 were investigated for this study. Afterwards, the patients were contacted by telephone. One hundred and nine patients reached were informed about the study and the patients were invited to the hospital for screening of DM with 75 gr OGTT. Twenty-five of the patients were not admitted to the hospital, while 6 of the patients were excluded since they were pregnant on admission. As a result, 78 patients at the postpartum $6^{\text {th }}-12^{\text {th }}$ months who had been admitted to the hospital and agreed to be included to the study were enrolled.

This study was approved by the local ethics committee. In our hospital, GDM screening is performed by a two step method. To all pregnant women, 50 gram glucose loading test in 1 hour is administered at the $24^{\text {th }}-28^{\text {th }}$ weeks of gestation. 100 gram OGTT in 3 hours is administered to patients, whose plasma glucose (PG) levels are $\geq 140 \mathrm{mg} / \mathrm{dl}$ (2). The diagnosis of GDM is based on the Carpenter and Coustan criteria (4).

The variables of the patients included in the study were interrogated after having been classified for 3 periods. The variables before pregnancy were regarded as; history of DM in first degree relatives, body mass index (BMI) and GDM history in previous pregnancies; while the variables during pregnancy were; age, number of pregnancies, polyclinic control number, treatment modality (diet, insulin), total number of hospitalization days and weight gain during pregnancy. The variables of the postpartum period were; BMI on admission and at the time of lactation. A BMI [weight $(\mathrm{kg}) /$ height ${ }^{2}\left(\mathrm{~m}^{2}\right)$ ] below $25 \mathrm{~kg} / \mathrm{m}^{2}$ was defined as normal, while $25-29.9 \mathrm{~kg} / \mathrm{m}^{2}$ was perceived as overweight and above 30 was considered as obese. In this study, patients were investigated after having been grouped according to their BMI values as below $25 \mathrm{~kg} / \mathrm{m}^{2}$, between $25-29.9 \mathrm{~kg} / \mathrm{m}^{2}$ and above $30 \mathrm{~kg} / \mathrm{m}^{2}$.

Diagnoses of type 2 DM, impaired glucose tolerance (IGT) and impaired fasting glucose (IFG) were made with 75 gram OGTT based on the suggestions of the World Health Organization (WHO) (6). The patients were divided into 3 groups according to their final diagnoses following 75 gram glucose loading test: (1)
Normal glucose tolerance (NGT) group (Patients with fasting plasma glucose (FPG) of $<110 \mathrm{mg} / \mathrm{dl}$ and the other normal OGTT measurement results); (2) IGT/IFG group (Patients with an FPG value of between 110-125 mg/dl and following the loading, when at the second hour the PG was between 140-199 mg/dl); (3) Type 2 DM group (Patients with FPG of $\geq 126 \mathrm{mg} / \mathrm{dl}$ or following the loading, when at the second hour the PG was $\geq 200 \mathrm{mg} / \mathrm{dl}$ ).

PG concentrations were measured using the standard glucose oxidase method from venous plasma samples (Glucose Analyzer II, Beckmann-Coulter).

\section{Statistical analysis}

All data were recorded and evaluated using the SPSS (Statistical Package for Social Sciences) program. $\chi^{2}$ analysis was used for the categorical data. The Mann-Whitney U test was used in the comparison of the 2 groups, and the Kruskall-Wallis test was used in the comparison of 3 or more groups. Furthermore, logistic regression analysis was performed for the calculation of risk coefficients. The significance level was set as $\mathrm{p}<0.05$.

\section{Results}

In the evaluation of patients with 75 gram OGTT, while the results of 23 cases (29.5\%) were normal, the results of 28 cases (35.9\%) were compatible with IGT/IFG, and in 27 cases (34.6\%), DM was determined (Figure 1). The clinical and laboratory data of patients included in the study have been summarized in Table 1 under the headings of variables of before pregnancy, during pregnancy and the postpartum period. In the investigation of patients regarding the presence of risk factors before pregnancy, the presence of DM in first degree relatives was at the rate of $77.8 \%(n=21)$ in patients diagnosed with $D M, 64.3 \%$ $(n=18)$ in patients with IGT/IFG, and 39\% $(n=9)$ in patients with NGT, and the presence of DM in the family history was statistically significantly higher than in other groups of patients diagnosed with DM $(\mathrm{p}=0.018)$.

In the evaluation of the medical histories of patients, a GDM

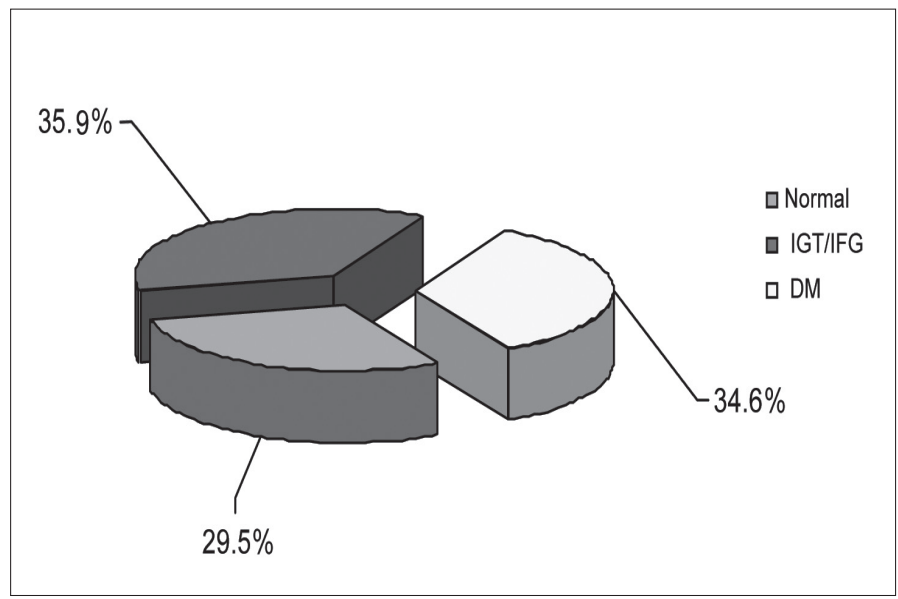

Figure 1. The evaluation rates with $75 \mathrm{~g}$ OGTT at the $6^{\text {th }}-12^{\text {th }}$ postpartum months 
Table 1. Patients' clinical and metabolic characteristics [mean \pm SD or $\%(n)]$

\begin{tabular}{|c|c|c|c|c|}
\hline & $\begin{array}{c}\text { NGT } \\
(n=23)\end{array}$ & $\begin{array}{c}\text { IGT/IFG } \\
(n=28)\end{array}$ & $\begin{array}{c}\mathrm{DM} \\
(\mathrm{n}=27)\end{array}$ & $\mathbf{p}$ \\
\hline \multicolumn{5}{|l|}{ Variables before pregnancy } \\
\hline Presence of family history & $39 \%(9)$ & $64.3 \%(18)$ & $77.8 \%(21)$ & $\mathrm{p}=0.018$ \\
\hline BMI before pregnancy $\left(\mathrm{kg} / \mathrm{m}^{2}\right)$ & $25.7 \pm 4.6$ & $27.4 \pm 4.9$ & $30.1 \pm 4.4$ & $\mathrm{p}=0.009$ \\
\hline GDM history in previous pregnancies & $8.7 \%(2)$ & $14.3 \%(4)$ & 0 & $*$ \\
\hline \multicolumn{5}{|l|}{ Variables during pregnancy } \\
\hline Age (year) & $23 \pm 3.5$ & $33.3 \pm 5.4$ & $37 \pm 2.8$ & $\mathrm{P}<0.05$ \\
\hline $\begin{array}{l}\text { Primiparous } \\
\text { Multiparous }\end{array}$ & $\begin{array}{c}8.7 \%(2) \\
91.3 \%(21)\end{array}$ & $\begin{array}{l}35.7 \%(10) \\
64.3 \%(18)\end{array}$ & $\begin{array}{c}7.4 \%(2) \\
92.6 \%(25)\end{array}$ & $\mathrm{p}=0.02$ \\
\hline Insulin treatment & $8.7 \%(2)$ & $57.1 \%(16)$ & $92.6 \%(25)$ & $\mathrm{p}<0.05$ \\
\hline Weight gain during pregnancy (kg) & $10.2 \pm 5.6$ & $10.1 \pm 7$ & $9.2 \pm 4.4$ & $\mathrm{p}>0.05$ \\
\hline Total days of hospitalisation & $10.5 \pm 9.4$ & $12.9 \pm 10$ & $12.9 \pm 10.8$ & $\mathrm{p}>0.05$ \\
\hline $\begin{array}{l}\text { Polyclinic control number } \quad \begin{array}{r}(0-9) \\
(10-20)\end{array}\end{array}$ & $\begin{array}{l}47.8 \%(11) \\
52.2 \%(12)\end{array}$ & $\begin{array}{l}35.7 \%(10) \\
64.3 \%(18)\end{array}$ & $\begin{array}{l}44.4 \%(12) \\
55.6 \%(15)\end{array}$ & $\mathrm{p}>0.05$ \\
\hline \multicolumn{5}{|l|}{ Variables of the postpartum period } \\
\hline Postpartum BMI (kg/m²) & $28.3 \pm 5.3$ & $29 \pm 4.3$ & $30.7 \pm 5.2$ & $\mathrm{p}>0.05$ \\
\hline Lactation & $\begin{array}{l}43.4 \%(10) \\
56.5 \%(13)\end{array}$ & $\begin{array}{l}14.3 \%(4) \\
85.7 \%(24)\end{array}$ & $\begin{array}{c}14.8 \%(4) \\
85.2 \%(23)\end{array}$ & $\mathrm{p}>0.05$ \\
\hline
\end{tabular}

history in previous pregnancies was questioned. However, since this was the first pregnancy in 14 patients and in 21 multiparous patients, results of GDM in previous pregnancies in only 43 patients could be accessed. In those patients, 6 (7.7\%) had received the diagnosis of GDM in previous pregnancies, but due to the low number of cases, statistical analysis could not be performed.

The mean BMI before pregnancy was calculated as $30.1 \pm 4.4$ $\mathrm{kg} / \mathrm{m}^{2}$ in patients diagnosed with DM, $27.4 \pm 4.9 \mathrm{~kg} / \mathrm{m}^{2}$ in patients with IGT/IFG, and $25.4 \pm 4.6 \mathrm{~kg} / \mathrm{m}^{2}$ in the NGT group. The mean BMI before pregnancy was statistically significantly higher than that in other groups in patients diagnosed with DM $(p=0.009)$. The mean BMI before pregnancy was re-evaluated after having been grouped, as below $25 \mathrm{~kg} / \mathrm{m}^{2}$, between $25-29.9 \mathrm{~kg} / \mathrm{m}^{2}$, and above $30 \mathrm{~kg} / \mathrm{m}^{2}$. This evaluation revealed that the development of DM in the postpartum period in patients with a BMI higher than $30 \mathrm{~kg} / \mathrm{m}^{2}$ before pregnancy was significantly higher than that of the other 2 groups $(\mathrm{p}<0.05)$ (Figure 2).

In the investigation of variables during the pregnancy period, the mean age during pregnancy was $37 \pm 2.8$ years in patients diagnosed with DM, 33.3 \pm 5.4 in patients diagnosed with IGT/ IFG, and $23.5 \pm 3.5$ in patients with NGT. The mean age was observed to be lower than the DM group in patients diagnosed with NGT and IGT/IFG ( $<<0.05)$.

Sixty-four (82\%) cases included in the study were multiparous, while $14(18 \%)$ cases were primiparous. In the analysis of the effects of parity on the diagnosis of postpartum DM, $92.6 \%$ of the patients diagnosed with DM were multiparous. In the logistic regression analysis among patients diagnosed with DM $(n=27)$ and other patients $(n=51)$, multiparity was found as a significant factor affecting the model $(\mathrm{p}<0.05, \mathrm{OR}=2)$.

The insulin treatment rate for GDM was found as $92.6 \%(n=25)$ in patients diagnosed with postpartum DM, 57.1\% $(n=16)$ in patients with IGT/IFG, and $8.7 \%(n=2)$ in patients with NGT. Among patients diagnosed with DM, the insulin treatment rate during pregnancy was found to be statistically significant $(p<0.05)$. In the logistic regression analysis, an increase in the rate of insulin use increased the risk of development of DM development 7.27-fold ( $\mathrm{p}<0,05 \mathrm{OR}=7,27$ ).

The total number of hospitalization days for blood glucose regulation and the number of polyclinic outpatient admission days were similar in all 3 groups.

The effects of lactation, which is one of the postpartum period variables, on the postpartum glycemic status were investigated after having been divided into 2 groups as shorter than 6 months, or longer than 6 months; however, no significant effects of lactation on the postpartum glycemic status was observed.

Postpartum BMI, calculated at the time of enrolment in the study was not different between the 3 groups. The cases were also investigated for postpartum BMI parameters after having been grouped as: lower than $25 \mathrm{~kg} / \mathrm{m}^{2}$, between $25-29.9 \mathrm{~kg} / \mathrm{m}^{2}$, and above $30 \mathrm{~kg} / \mathrm{m}^{2}$; however, no statistically significant difference was determined (Figure 3 ). 


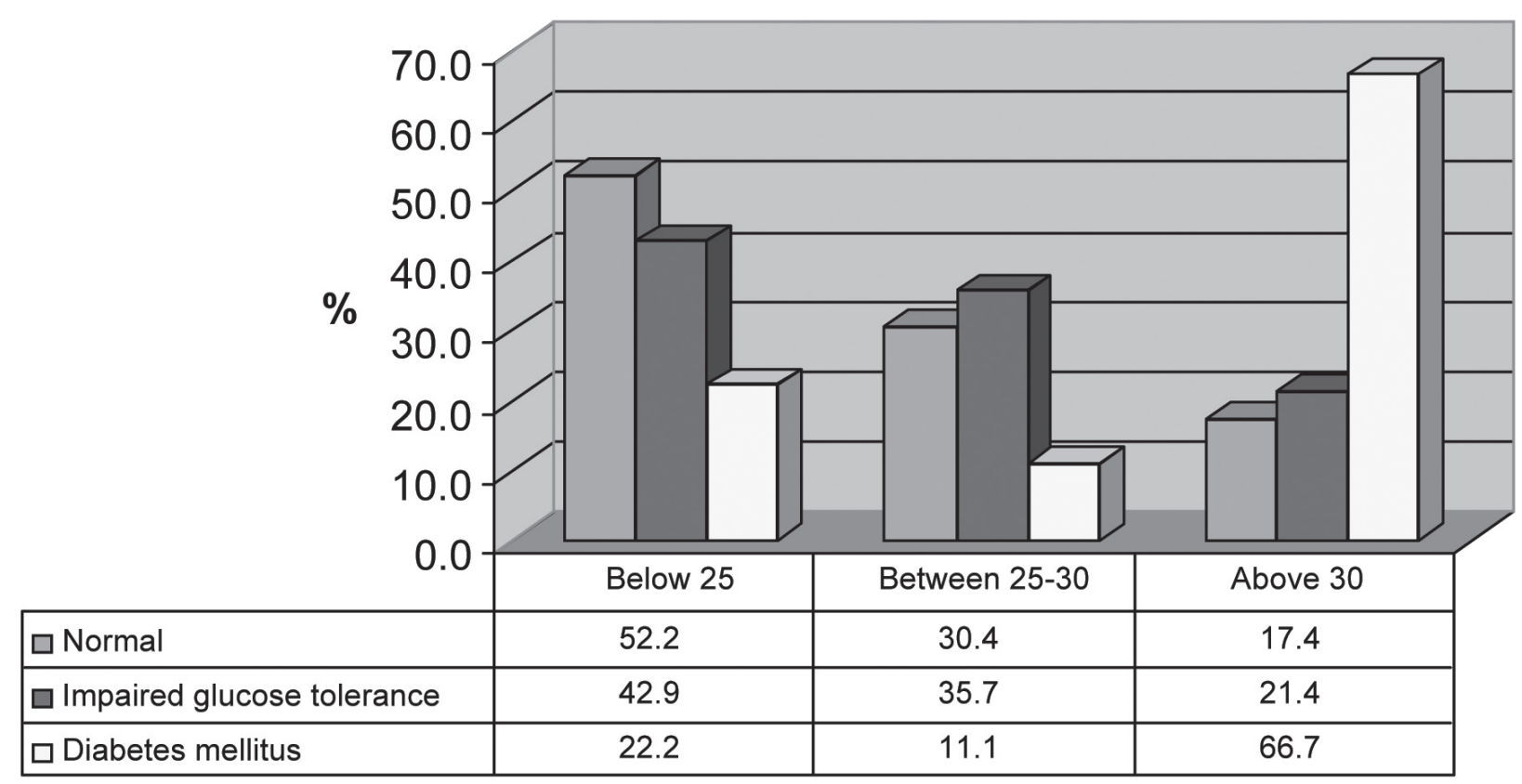

Figure 2. The association of BMI before pregnancy with postpartum glycemic status $\left(\%, \mathbf{k g} / \mathrm{m}^{2}\right)$

\section{Discussion}

In this study, in the evaluation of patients with GDM in the postpartum $6^{\text {th }}-12^{\text {th }}$ months, IGT/IFG was determined at a rate of $35.9 \%$ and DM was determined at a rate of $34.6 \%$. There are many studies reporting the results of screening of postpartum DM development among women who had GDM in their pregnancies. In the evaluation of these studies, which determined the results up to the end of the first year after delivery, similar to our study, the reported type 2 DM development rate was between $2 \%$ and $38 \%$, and the IGT development rate changed between $7-21 \%$ (7-11). In our study, the higher rates of DM and IGT/IFG development than that in the literature may be due to differences in populations and follow-up periods of studies, variations in patient populations, and/or diagnostic criteria, as well as the limitations of this study.

The lack of determination of diabetes and glucose intolerance in the included patients before pregnancy is one of the limitations of this study. The possibility of the presence of diabetes or impaired glucose tolerance before pregnancy among patients diagnosed with GDM may explain these high rates in the postpartum period. Another limitation of this study is that auto-antibodies defining the presence of type DM were not determined. Hence, this high rate includes all DM cases. However, since the rate of type $1 \mathrm{DM}$ among all patients diagnosed with DM is as low as $2.3 \%-9.3 \%$ in studies with follow-up periods ranging between 1-10 years in the literature, the high rate of DM we determined in the postpartum first year cannot be explained with this factor alone (16-19).

In the study of Costa et al. on the Spanish population, the prevalence of type $2 \mathrm{DM}$ at the $2^{\text {nd }}-12^{\text {th }}$ postpartum month period was determined as $2 \%$, which is lower than that in the literature and in our study. The reason for this may be ethnic origin, as well as the use of the 1985 WHO criteria to diagnose DM with OGTT in this study (11). In the study of Lam on the Chinese population, in the postpartum first year, the rate of DM diagnosis following GDM was reported as 5\%, and the rate for IGT diagnosis was found to be $8 \%$. The differentiation of this study from our study and other studies and the reason for the low DM prevalence in this study was probably the exclusion of cases with normal results on the first glycemic status evaluation at the sixth week after delivery (9).

Despite the presence of studies reporting that ethnic origin does not have primary importance, there are studies associating the prevalence of postpartum type 2 DM they determined following GDM, directly with de novo type 2 DM development rates in the population study $(5,12-14)$. In our country, there is no specific screening program for DM except for the pregnancy period. A few years ago, in the Turkish Diabetes Epidemiology study (TURDEP), the DM prevalence in our adult population was defined as $7.2 \%$ and the IGT prevalence was defined as 6.7 , and they have been reported more commonly in women than men (15). When the 7.2\% DM prevalence reported in TURDEP is considered, the high rates of postpartum type $2 \mathrm{DM}$ development in our patient population cannot be associated with de novo type 2 DM development.

As in many studies, we also demonstrated the increased risk of postpartum DM development following GDM in patients with DM in first degree relatives $(7,9,10,20)$. Although the history of GDM in previous pregnancies was not a clearly evaluated variable in our study, many researchers have defined this variable as a predicting factor for development of DM in the future (21-23). 


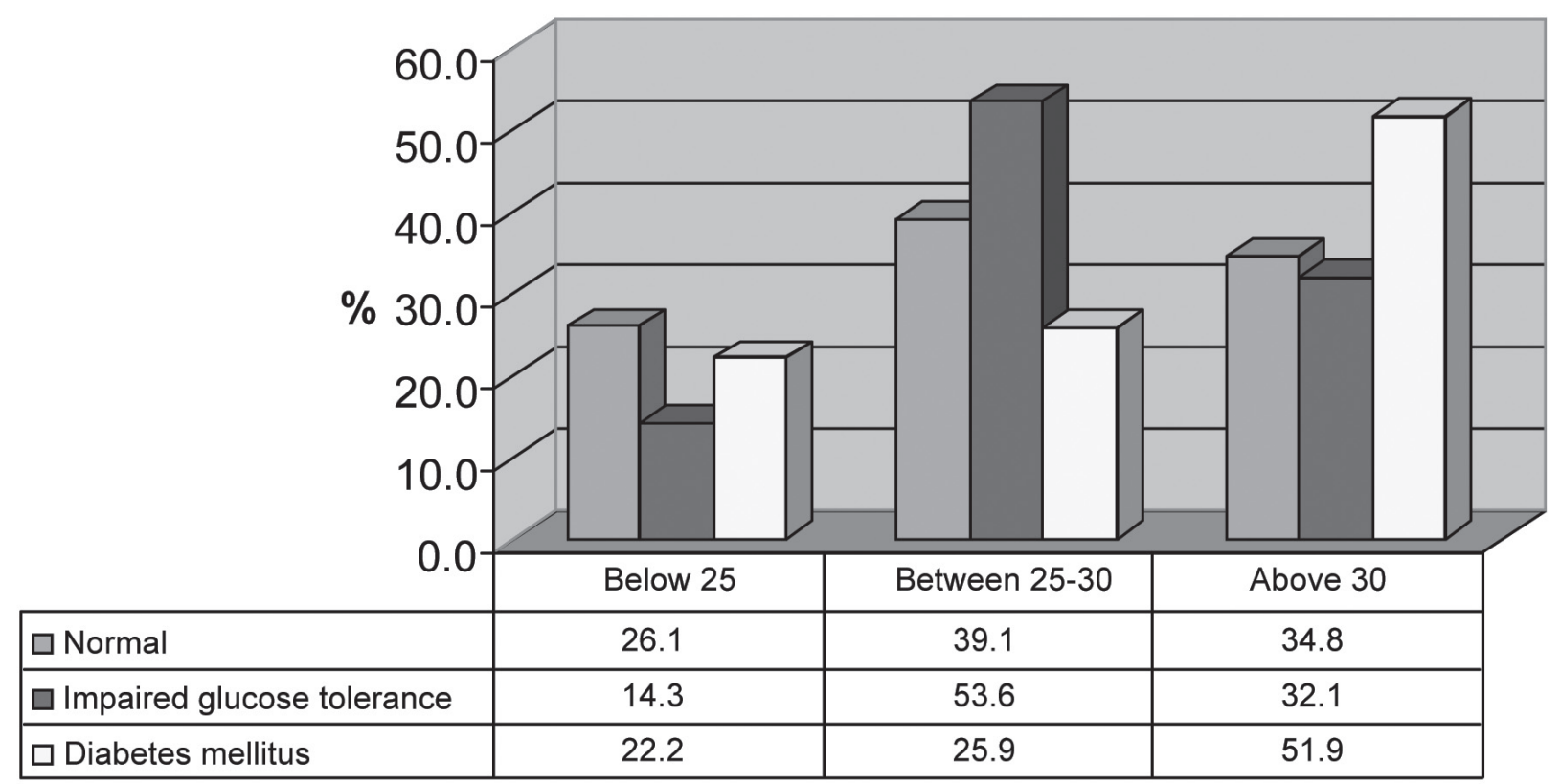

Figure 3. The association of BMI after delivery with postpartum glycemic status $\left(\%, \mathrm{~kg} / \mathrm{m}^{2}\right)$

When the clinical features of patients in our study were evaluated, it could be stated that the age of the patients diagnosed with DM at the postpartum period during index pregnancies were significantly higher than that of other patients. Older age has been described as a classic risk factor in the development of postpartum DM in many studies, and has also been confirmed in our study and the importance of cautious follow-up of pregnant women who are in an older age group and with obesity has been emphasized $(21,24)$.

In many studies in the literature, the association of parity with glycemic status after delivery could not be demonstrated (9, 20, $23,25,26)$. However, in our study, it has been determined that multiparity increases the risk of DM development; but up to $82 \%$ of the patient population in our study was multiparous, which may be the reason for this difference from that in the literature $(\mathrm{p}<0.05 \mathrm{OR}=2)$.

In this study, the rate of incidence of postpartum DM development in the first year among patients treated with insulin for GDM was found to be higher than that of other patients $(p<0.05$ $\mathrm{OR}=7.27$ ). The necessity of insulin use during pregnancy was also defined as a factor with high predictive value for the development of DM in the future in the literature $(9,21,28-30)$.

The total number of hospitalisation days and polyclinic control were evaluated since they consequently show poor glycemic control and the necessity of more common assessment, but there was no significant difference between patients diagnosed with DM and those not diagnosed with DM.

Nowadays, one of the most important factors affecting human health all over the world is obesity. Supporting many previous studies in the literature, in this study, the BMI before pregnancy was found to be significantly higher among patients diagnosed with postpartum DM $(16,21,29,31)$. However, similar to the literature, there was no significant difference between patients diagnosed with DM and the other patients with regard to weight gain during pregnancy and BMI calculated on admission to the study, but it was noteworthy that the mean of this variable for all patients was $29.4 \mathrm{~kg} / \mathrm{m}^{2}$. In the studies performed, since the development of DM depends on many different mechanisms, it has been suggested that obesity cannot be solely blamed as the responsible factor in the etiology $(25,32)$.

In our study, lactation did not have a significant effect on postpartum glucose tolerance. Similarly, in the literature, although the positive effects of lactation on the glycemic status of the mother could not be clearly demonstrated, there are studies demonstrating that it decreases the high feeding rates in babies, and the rate of these babies being overweight-obese is lower and consequently lactation should be supported in these patients (2, 33-35).

Cumulative incidence of postpartum DM shows a fast rise in GDM patients in the first 5 years, and in the 5-10-year period, and although the increase continues, the acceleration decreases (5). These patients should be followed-up for a longer duration in order to contribute to the public data. If the results of this study, that 1 in every 3 GDM patients receives the diagnosis of DM in the first year after delivery and similarly 1 in every 3 patients also receives the diagnosis of IGT, which is a risk factor for DM, are taken into account, the most important health target for a GDM-diagnosed pregnant woman in the postpartum period is the prevention of DM development, which is a chronic disease that negatively affects the quality of life, has an expensive treatment and severe complications.

\section{Conflict of interest}

None declared 


\section{References}

1. Lain KY, Catalano PM. Metabolic changes in pregnancy. Clin Obstet Gynecol 2007; 50: 938-48.

2. American Diabetes Assosiation: Gestational diabetes mellitus (Position Statement). Diabetes Care 2004; 27 (Suppl. 1): S88-S90.

3. Karcaaltincaba D, Kandemir O, Yalvac S, Guvendag-Guven S, Haberal A. Prevalence of gestational diabetes mellitus and gestational impaired glucose tolerance in pregnant women evaluated by National Diabetes Data Group and Carpenter and Coustan criteria. Int J Gynaecol Obstet. 2009; 106: 246-9.

4. Carpenter MW, Coustan DR. Criteria for screening tests for gestational diabetes.Am J Obstet Gynecol 1982; 144: 768-73.

5. Kim C, Newton KM, Knopp RH. Gestational diabetes and the incidence of type 2 diabetes: a systematic review. Diabetes Care 2002; 25: $1862-8$

6. World Health Organization. Definition and diagnosis of diabetes mellitus and intermediate hyperglycemia: Report of a WHO/IDF consultation, 2006:1-46.

7. Aberg AE, Jonsson EK, Eskilsson I, Landin-Olsson M, Frid AH. Predictive factors of developing diabetes mellitus in women with gestational diabetes mellitus. Acta Obstet Gynecol Scand 2002; 81: 11-6.

8. Ekelund M, Shaat N, Almgren P, Groop L, Berntorp K. Prediction of postpartum diabetes in women with gestational diabetes mellitus. Diabetologia 2010; 53: 452-7.

9. Lam KS, Li DF, Lauder IJ, Lee CP, Kung AW, Ma JT. Prediction of persistent carbonhydrate intolerance in patients with gestational diabetes. Diabetes Res Clin Pract 1991; 12: 181-6.

10. Farrell J, Forrest JM, Storey GN, Yue DK, Shearman RP, Turtle JR. Gestational diabetes-infant malformations and subsequent maternal glucose tolerance. Aust N Z J Obstet Gynaecol 1986; 26: 11-6.

11. Costa A, Carmona F, Martinez-Roman S, Quintó L, Levy I, Conget I. Post-partum reclassification of glucose tolerance in women previously diagnosed with gestational diabetes mellitus. Diabet Med. 2000; 17: 595-8.

12. Kitzmiller JL, Dang-Kilduff L, Taslimi MM. Gestational diabetes after delivery: Short-term management and long-term risks. Diabetes Care 2007; 30 (Suppl. 2): 225-35.

13. Yogev Y, Langer O, Xenakis EM, Rosenn B. Glucose screening in Mexican-American women. Obstet Gynecol 2004; 103: 1241- 5.

14. Weijers RN, Bekedam DJ, Goldschmidt HM, Smulders YM. The clinical usefulness of glucose tolerance testing in gestational diabetes to predict early postpartum diabetes mellitus. Clin Chem Lab Med 2006; 44: 99-104.

15. The TURDEP Group (Satman I, Yllmaz T, Sengül A, Salman S, Salman F, Uygur S ve ark:) Population-based study of diabetes and risk characteristics in Turkey. Results of the Turkish diabetes epidemiology study (TURDEP). Diabetes Care 2002; 25: 1551-5.

16. Albareda M, Caballero A, Badell G, Piquer S, Ortiz A, de Leiva A, Corcoy R. Diabetes and abnormal glucose tolerance in women with previous gestational diabetes. Diabetes Care 2003; 26: 1199-205.

17. Cypryk K, Czupryniak L, Wilczynski J, Lewinski A. Diabetes screening after gestational diabetes mellitus: poor performance of fasting plasma glucose. Acta Diabetol 2004; 41: 5-8.

18. Lauenborg J, Hansen T, Jensen DM, Vestelgaard H, Molsted-Pedersen L, Hornnes P, et al. Increasing incidence of diabetes after gestational diabetes: a long-term follow-up in a Danish population. Diabetes Care 2004; 27: 1194-9.
19. Hunger-Dathe W, Mosebach N, Samann A, Wolf G, Müller UA. Prevalance of impaired glucose tolerance 6 years after gestational diabetes. Exp Clin Endocrinol Diabetes 2006; 114: 11-7.

20. Kjos SL, Peters RK, Xiang A, Thomas D, Schaefer U, Buchanan TA Contraception and the risk of type 2 diabetes mellitus in Latino women with prior gestational diabetes mellitus. JAMA 1998; 280: 533-8.

21. Pallardo F, Herranz L, Garcia-Ingelmo T, Grande C, Martin-Vaquero P, Janez M et al. Early postpartum metabolic assesment in women with prior gestational diabetes. Diabetes Care 1999; 22: 1053-8.

22. Schaefer-Graf UM, Buchanan TA, Xiang AH, Peters RK, Kjos SL. Clinical predictors for a high risk fort the development of diabetes mellitus in the early puerperium in women with gestational diabetes mellitus. Am J Obstet Gynecol 2002; 186: 751-6.

23. Kaufmann R, Schleyhahn F, Huffman D, Amankwah K. Gestational diabetes diagnostic criteria: long term maternal follow-up. Am J Obstet Gynecol 1995; 172: 621-5.

24. Kjos SL, Buchanan TA, Greenspoon JS, Montoro M, Bernstein GS, Mestman JH. Gestational diabetes mellitus: the prevalance of glucose intolerance and diabetes mellitus in the first two months postpartum. Am J Obstet Gynecol 1990; 163: 93-8.

25. Lee AJ, Hiscock RJ, Wein P, Walker SP, Permezel M. Gestational diabetes mellitus: Clinical predictors and long term risk of developing type 2 diabetes. A retrospective cohort study using survival analysis. Diabetes Care 2007; 30: 878-83.

26. Metzger BE, Coustan DR, Organizing Committee: Summary and recommendations of the Fourth International Workshop-Conference on Gestational Diabetes Mellitus. Diabetes Care 1998; 21 (Suppl. 2): B161-B167.

27. Löbner K, Knopff A, Baumgarten A, Mollenhauser U, Marienfeld S, Garrido-Franco $\mathrm{M}$ et al. Predictors of postpartum diabetes in women with gestational diabetes mellitus. Diabetes 2006; 55: 792-7.

28. Karakurt F, Çarlıoğlu A, Kasapoğlu B, Gümüș Iï. Gestasyonel diyabetes mellitus tanı ve tedavisi. Yeni Tıp Dergisi 2009; 26: 134-8.

29. Schaefer-Graf UM, Klavehn S, Hartmann R, Kleinwechter H, Demandt N, Soger M, et al. How do we reduce the number of cases of missed postpartum diabetes in women with recent gestational diabetes mellitus? Diabetes Care 2009; 32: 1960-4.

30. Dalfrá MG, Lapolla A, Masin M, Giglia G, Dalla Barba B, Toniato R, et al. Antepartum and early postpartum predictors of type 2 diabetes development in women with gestational diabetes mellitus. Diabetes Metab (Paris) 2001; 27: 675-80.

31. Lauenborg J, Mathiesen ER, Damm P. Diabetology of pregnancy. Front Diabetes.Long term consequences of gestational diabetes mellitus. Djelmiš J, Desoye G, Ivaniševič M (edt). Basel, Karger, 2005; 17: 310-9.

32. Buchanan TA, Xiang AH, Kjos SL, Trigo E, Lee WP, Peters RK. Antepartum predictors of the development of type 2 diabetes in Latino women 11-26 months after pregnancies complicated by gestational diabetes. Diabetes 1999; 48: 2430-6.

33. Gunderson EP, Lewis CE, Wei GS, Whitmer RA, Quesenberry CP, Sidney S. Lactation and changes in maternal metabolic risk factors. Obstet Gynecol 2007; 109: 729-38.

34. Arenz S, von Kries R. Protective effect of breastfeeding against obesity in childhood: can a meta-analysis of observational studies help to validate the hypothesis? Adv Exp Med Biol 2005; 569: 40-8.

35. Grummer-Strawn LM, Mei Z. Does breastfeeding protect against pediatric overweight? Analysis of longitudinal data from the centers for disease control and preventation pediatric nutrition surveillance system. Pediatrics 2004; 113: e81-e86. 